\title{
A Study on Quality of Life in Mathare, Nairobi, Kenya
}

\author{
Dan Darkey and Angela Kariuki \\ Department of Geography, Geoinformatics and Meteorology, University of Pretoria, \\ Pretoria, South Africa
}

\author{
KEYWORDS Quality of Life. Slum. Urbanisation. Nairobi
}

\begin{abstract}
Sub-Saharan Africa hosts the highest number of urban slum households in the world with an estimated 60 to $70 \%$ of urban residents living in slums. Kenya belongs to this region and has large informal settlements with dire socio-economic conditions. This study on the quality of life, in a typical East African slum, is based on fieldwork carried out in Mathare, Nairobi. The research revealed that Mathare residents prioritise sanitation, waste management and access to water, electricity, education and healthcare as the most essential services for adding quality to their lives. However, one of the main conclusions of this research is that although improved service delivery is necessary, it may not be sufficient in satisfying the quality of life requirements of Mathare residents. Other aspects of economics, such as regular employment as well as socio-cultural issues, like freedom from fear and access to communal security, are equally important and policy objectives should pay holistic attention to both the objective living conditions and the subjective life satisfaction indicators of slum dwellers.
\end{abstract}

\section{INTRODUCTION}

\section{The Roots of Socio-economic Inequality in Kenya}

Kenya (see location of the country in Fig. 1) was colonised by the British and gained independence in December 1963. The history of Nairobi illustrates the British colonial policy of social and spatial segregation. At the end of the $19^{\text {th }}$ century the British rulers were building a railway to connect the coast of Kenya with Uganda (Campbell 2005). Halfway along the railway construction site, a location was needed to function as railway headquarters, so the British created Nairobi in 1899 (Campbell 2005). Nairobi became the capital of Kenya in 1905. Most of the railway labourers were Indians, who still form a significant part of the city's population. From the onset, Nairobi was spatially designed to separate the main communities into different neighbourhoods. Like many African cities, 'economic growth' in Nairobi has not prevented the social and economic ills of marginalisation of minority groups, degradation of the environment, and the

Address for correspondence:

Dr. Dan Darkey

Department of Geography,

Geoinformatics and Meteorology,

University of Pretoria,

Pretoria, South Africa

Phone: +27 124203719 or +27828526782

E-mail: daniel.darkey@up.ac.za rising costs of health care and education (UNDP 2007).

Many colonial laws and policies were enacted to maintain the spatial segregation. Black people were not allowed to settle in urban areas, they were only tolerated in the city as temporary workers. The attitude of the municipal authority towards African housing was articulated in 1930: "It seems only right that it should be understood that the town is a non-native area in which there is no place for the redundant native, who neither works nor serves his or her people. The exclusion of these redundant natives is in the interest of natives and non-natives alike..." (Van Zwanenberg and King, cited in Campbell 2005:8). Lonsdale (cited in Campbell 2005:6) adds “... Nairobi was a perfect Apartheid city without trying. The colonial government was a state of exclusion: it divided the society between those who had rights of citizenship and those who did not - the urban and the rural respectively". The post-colonial government did not change the 'bifurcated state' following independence in 1963. Instead, Nairobi grew rapidly and the city has remained one of the urban centres with the highest growth rates in Africa (SID 2006). By 2010 Nairobi's growth rate was estimated to be as high as $4.1 \%$ (CIA 2010).

After independence, the structural inequality between poor and rich increased, putting Kenya among the top ten most unequal countries in the world (Campbell 2005). The main causal factors for inequality in Kenya are poverty, scarcity of resources and a weak budgetary sys- 


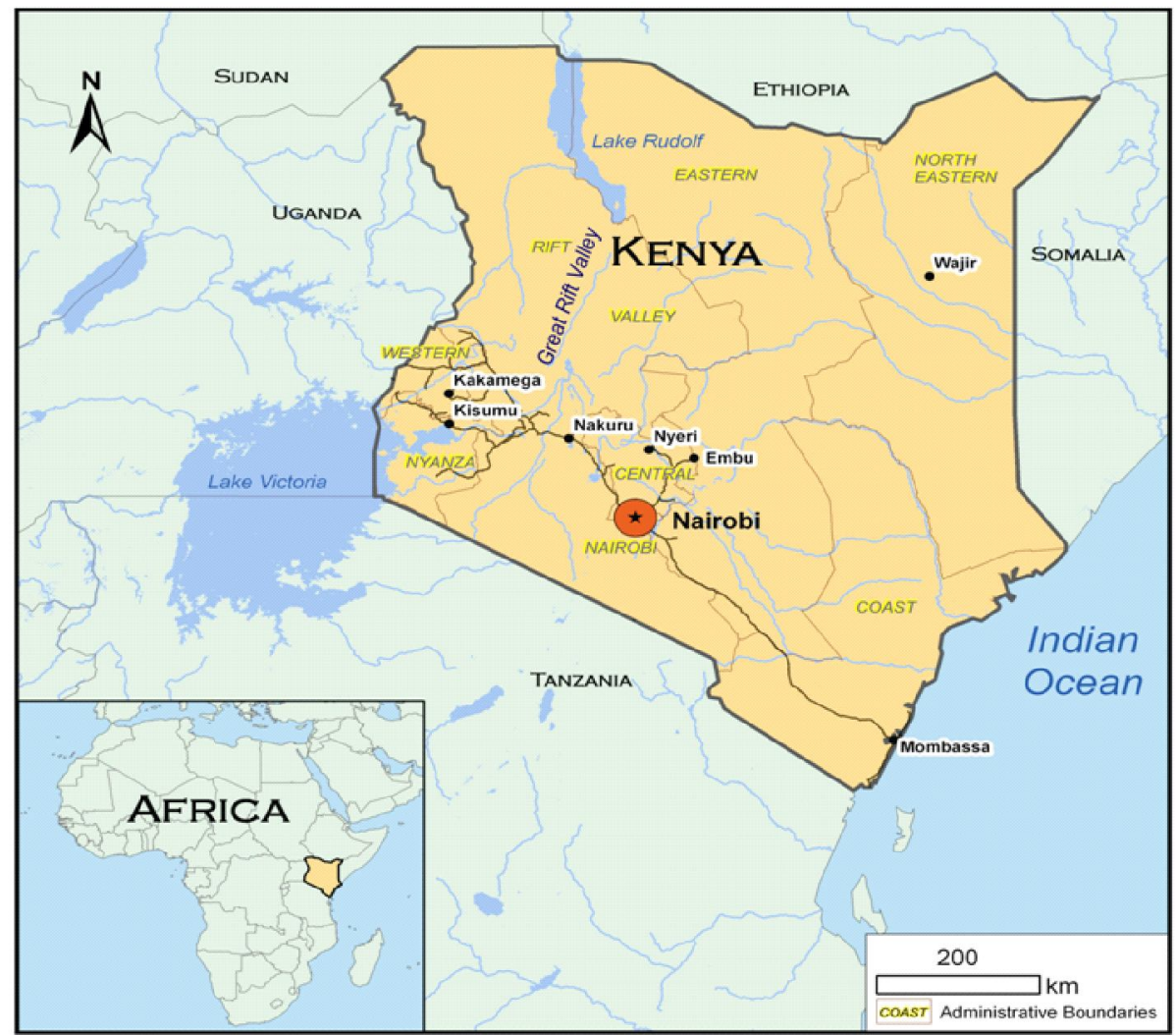

Fig. 1. Map of Kenya indicating Nairobi (Source: www.victoryhope.nl)

tem. The World Bank states in its Development Report of 2006 that in a more equal society, the same level of growth would result in a higher rate of poverty reduction than in a society with high levels of inequality (World Bank 2006). Kenya is still in a state where inequality is increasing (SID 2006).

Nairobi is also referred to as the 'self-help city'; many poor people work in the informal sector. The activities in this sector range from painting, carpentry, shoe-making, driving and domestic services, to petty trading and hawking of various food commodities. The informal sector contributes significantly to Nairobi's economy and has strong backward linkages with commercial and public enterprises. However, unemployment is widespread, especially among young urban dwellers and women (Rakodi 1997). Part of the reason for the high unemployment may be because the post-independence ruling elite continue to practice more or less the same discriminatory policies against the poor populations as the white settlers did over 50 years ago. Many people living in Nairobi are not able to access the 'formal' economy or professional jobs. As pointed out by the UN-Habitat (2009), working in the informal economy is nothing more than a survival strategy that people use when they do not have a job opportunity or source of income in the formal economy. Without adequate access to formal employment, they have limited income and are forced to live in slums like Mathare. The study aims to reveal their socioeconomic conditions and understand their notion of quality of life.

\section{Objectives}

This paper seeks to understand the subjective and objective notions of quality of life with 
regards to the people of Mathare. In light of these, specific research questions would include:

- What do the people of Mathare consider as essential for satisfaction with life and for happiness?

- What are their perceptions on the concept of quality of life?

- What are their priorities in terms of improving their quality of life?

- Do they have easy access to basic services such as water, sanitation, housing and energy?

- What are their motivation for moving to and staying in Mathare?

- What are their relationship with, and assessment of, local government and institutions like the City Council of Nairobi?

The paper is presented in four sections. The first provides a context of the historical inequalities in socio-economic conditions and the settlement patterns of people in Kenya, following the period of colonialism. Section two reviews the literature related to informal settlements and the quality of life therein. The literature review enables the conceptualisation of the quality of life in terms of subjective well-being and establishes the population-poverty-environment link. Section three provides a description of the socio-economic and physical environment of Mathare - the study area and provides an insight into the Mathare society. The study results, conclusions and recommendations emanating from the analysis are presented in section four.

\section{Literature Review}

\section{Quality of Life Studies}

Early quality of life studies measured development in terms of economic growth and per capita gross domestic product (GDP) (Nussbaum and Sen 1993). At the start of the 1960s however, such focused studies began to be regarded as narrow. This led to a wider range of social and economic indicators being investigated to establish a more holistic view of the way people live (Beukes and Van der Colff 1997). In essence, while economic indicators point to a race between the poor and the rich and indicate that the poor have some 'catching up' to do, social indicators identify common values, problems and opportunities for learning from and cooperating with one another. In contrast to economic indicators, social indicators have the tendency to shed some light on the human, social and cultural contexts of poverty (Beukes and Van der Colff 1997). Generally, social indicators refer to attempts made to measure the contribution to well-being with regard to aspects such as health, nutrition, housing, income distribution, access to natural resources, freedom from fear, human rights, self-awareness, a clean environment and other aspects of a social and cultural nature (Diener and Suh 1997).

There are many ways to discover what people think they need and want, but research within the social indicators tradition (quality of life, subjective well-being, 'economics of happiness') provides an increasingly sophisticated and systematised body of approaches to this (Scheer 1980). A wide variety of methods have been developed to gather information on what people regard themselves as needing or wanting in order to achieve a good quality of life and provide insights into how satisfied they feel with the extent to which they are meeting those needs (Hagerty et al. 2001). The application of quality of life $(\mathrm{QoL})$ methods does generate indicators of the well-being of local populations and provide valuable additional information about what constitute 'needs satisfiers' for particular people, in particular social and geographical contexts (Diener and Suh 1997). However, people's opinion of their own quality of life provides the best indicators of how satisfied they are with their life and environment (Mngoma 1997).

Amartya Sen observed that we live in a world of exceptional opulence, of a kind that would have been difficult to imagine a century or two ago. People live much longer, on the average, than ever before. And yet we also live in a world with remarkable deprivation, destitution and oppression (Sen 1999). Overcoming these problems is a central part of the exercise of development. Though the concept of development has attracted different interpretations by various thinkers, a common feature of many of the explanations of the concept is that of expanding the real freedoms that people enjoy. Sen (1999: 3) for instance points out that "development has to be more concerned with enhancing the lives we lead and the freedoms we enjoy". In Mathare, residents suffer from varieties of a lack of freedom, such as the lack of access to basic services and confinements imposed, first by the colo- 
nial system and currently by insecure neighbourhoods. Another common thread that runs through most of the definitions of development is that there must be a significant improvement in the tangible and intangible welfare of the people concerned. It is thus important to also look at Bekker's (1992) interpretation of development where development (in a civilised society) is viewed as a process of improving the life chances and conditions of citizens, and in particular, of poor citizens.

Development as a concept includes physical, economic, social, and political development (Lombard 1991). Physical development is aimed at developing a specific area. Such development entails spatial development and provision of infrastructure. Economic development is primarily sectoral, aimed at agriculture, mining, trade and industry. Social development is aimed at the welfare of the total community and political development involves the community's understanding of political issues (Lombard 1991). Thus, there are a number of instrumental freedoms that contribute directly or indirectly, to the overall freedom people have to live the way they choose (Sen 1999). These instrumental freedoms include political freedoms, economic facilities, social opportunities, transparency guarantees, and protective security.

Todaro (1994) pointed out that in the 50s and 60s development was largely understood as rapid economic growth measured in terms of Gross Domestic Product (GDP). Real development however should be tuned to meeting the diverse basic needs and desires of individuals and social groups as it moves them away from the condition of life widely perceived as unsatisfactory, and towards a situation or condition of life regarded as materially and spiritually better (Todaro 1994; Young 1993). Koza (1976) holds a similar view in pointing out that development must be about the people and should be seen as a process by which efforts of the people themselves are united with authorities sponsoring development to improve economic, social and cultural conditions of the communities and to integrate these communities into the life of the nation enabling them to contribute fully to national progress. Indeed, a community can play a significant role in improving the quality of life for people, because it can enhance a feeling of security and improve the possibility for developing and maintaining an identity - important factors for quality of life (Davies 1993). Lastly, sustainable development entails self-reliant and cost-effective development, facilitating perpetual access to health, shelter, clean water and food and implies the need for people-centred initiatives (Munslow and Fitzgerald 1994; Ndlovu and Fairhurst 1996).

In Mathare, the people are slowly becoming part of the development of their own area. They own certain projects (discussed below), and these projects stem from ideas that were generated by circumstances of poverty and powerlessness.

\section{Concept of Quality of Life (QoL)}

Studies on QoL emerged in the 1960s as an extension to measuring development (Beukes and Van der Colff 1997). Prior to the 1960s, development had been linked solely to economic growth and GDP per capita was used as a measuring instrument (Beukes and Van der Colff 1997). It has since been accepted that material well-being, as measured by GDP per person, cannot alone explain the broader QoLin a country, or in this case, a particular settlement in a major city. A rise in GDP does not necessarily imply an increase in income and improvement in people's living conditions (Todaro 1994:163). Access to services and resources plays a great role in people's living conditions. This in turn reflects the quality of life that people enjoy.

Indeed since the 1980s more successful approaches to understanding and improving QoL have been developed. One of these approaches is the 'basic needs' approach. The 'basic needs' approach is supported by the World Bank and it seeks to meet the basic needs of the entire population of a developing country (Atte 1983:30). The concept of basic needs entails: basic consumption goods - food, clothing and shelter to which everyone is entitled; basic services such as education, health services, sanitation, clean water supply - to which everyone should have access and; the right to participate in making and implementing decisions which affect one's own development.

The basic needs approach tends to lean towards the use of economic indicators. Several studies have however used social indicators to measure the quality of life. Social indicators have their own strengths and weaknesses. Among the strengths of social indicators is objectivity, 
in that such indicators can be fairly quantified and defined. This enables cross-section and time series comparison with regard to information pertaining to such indicators, be it nationally or globally. One weakness of social indicators is the inevitable subjectivity that plays a part when a researcher decides on what indicators to select and what values to attach to those indicators (Diener and Suh 1997).

However, subjective well-being indicators are equally important for people to express their satisfaction or dissatisfaction with the conditions they happen to be in. This is despite the fact that people's expression of life satisfaction or dissatisfaction is generally a transformation of objective conditions that they experience, but it will be wrong to assume that this transformation is always automatic. As such it provides alternative views of assessing quality of life that are unlikely to be affected by common errors of measurement (Diener and Suh 1997).

QoL comprises two distinct global concepts. The first is perceived quality of life or life satisfaction, which is a result of satisfaction with the personal domains of life; this includes family life, friends, spouse, health and oneself. The second would then refer to the broader social environment, which would include housing, schools, health services, safety and security, and transport infrastructure (Westaway 2006). Personal QoL points to satisfaction with the broader social environment (Westaway 2006). Some people would rate their QoL as very good while they are living under extremely difficult environmental conditions, while others would rate their quality of life as poor even though the environmental conditions they live in are excellent (Westaway 2006). This is an illustration of how diverse people's views can be on quality of life.

A further theory on QoL can be derived from the human developmental perspective of psychologist Abraham Maslow (1943). In his works, Maslow formulated one of the most famous theories about basic human needs. He argues that fundamental human needs are hierarchically structured. At the base of the pyramid are the physiological needs for water, food and sleep; higher in the pyramid, after the fulfilment of the basic needs of having enough to drink and eat, and being safe, people feel the urge to create an identity and to develop themselves (Huitt 2007). The situation in Mathare somehow contradicts this hierarchy of needs. In Mathare migrants have their basic needs only partially fulfilled, but none of them completely. They do not aim to fulfil one level in the pyramid at a time, but they try to fulfil their needs at all levels simultaneously. Although people are physically hungry, they also hunger for safety, good health, esteem and an identity.

This paper attempts to determine how service delivery as an objective reality influences the residents of Mathare's QoL, which in turn is a subjective reality. In order to achieve this goal, criteria for both the objective and subjective realities had to be set. For the purposes of establishing criteria for service delivery (objective reality), the Nairobi City Council (CCN) minimum standard in terms of basic service delivery will be used as a point of departure. In establishing criteria for the QoL of Mathare's residents (subjective reality), it speaks for itself that only the residents of Mathare can define their own QoL.

\section{THE STUDY AREA}

Nairobi, the capital city of Kenya, covers an area of approximately 684 square kilometres, has a population estimated at three million and is East Africa's most populous city (CBS 2008). It also has various deep-rooted socio-economic challenges, including an overburdened infrastructure, unemployment, insufficient waste management, sprawl and an ever-enlarging informal housing sector (CBS 2008).

Nairobi's informal housing areas such as Mathare, tend to occupy marginal lands (flood plains, valleys, wetlands, waste dumps); be along railway tracks; lack infrastructure and facilities; have makeshift, substandard structures; are overcrowded; have inadequate potable water; lack proper sanitary facilities and have an absence of title and insecurity of tenure (CBS 2001). Mathare is the second biggest slum in Nairobi, following Africa's biggest slum, Kibera (Care International 2009; UN-Habitat 2010) which is also located in Nairobi, Kenya. Mathare was "built" over many years on top of a garbage dump as more and more people settled there (COHRE 2008). It is a long strip of tin and wooden shacks and earthen walls constructed on both sides of a small stream (see Fig. 2).

The number of inhabitants in Mathare is estimated at between 600,000 and 800,000 (COHRE 2008). It is closely located to the city centre about five kilometres from the Nairobi Central 


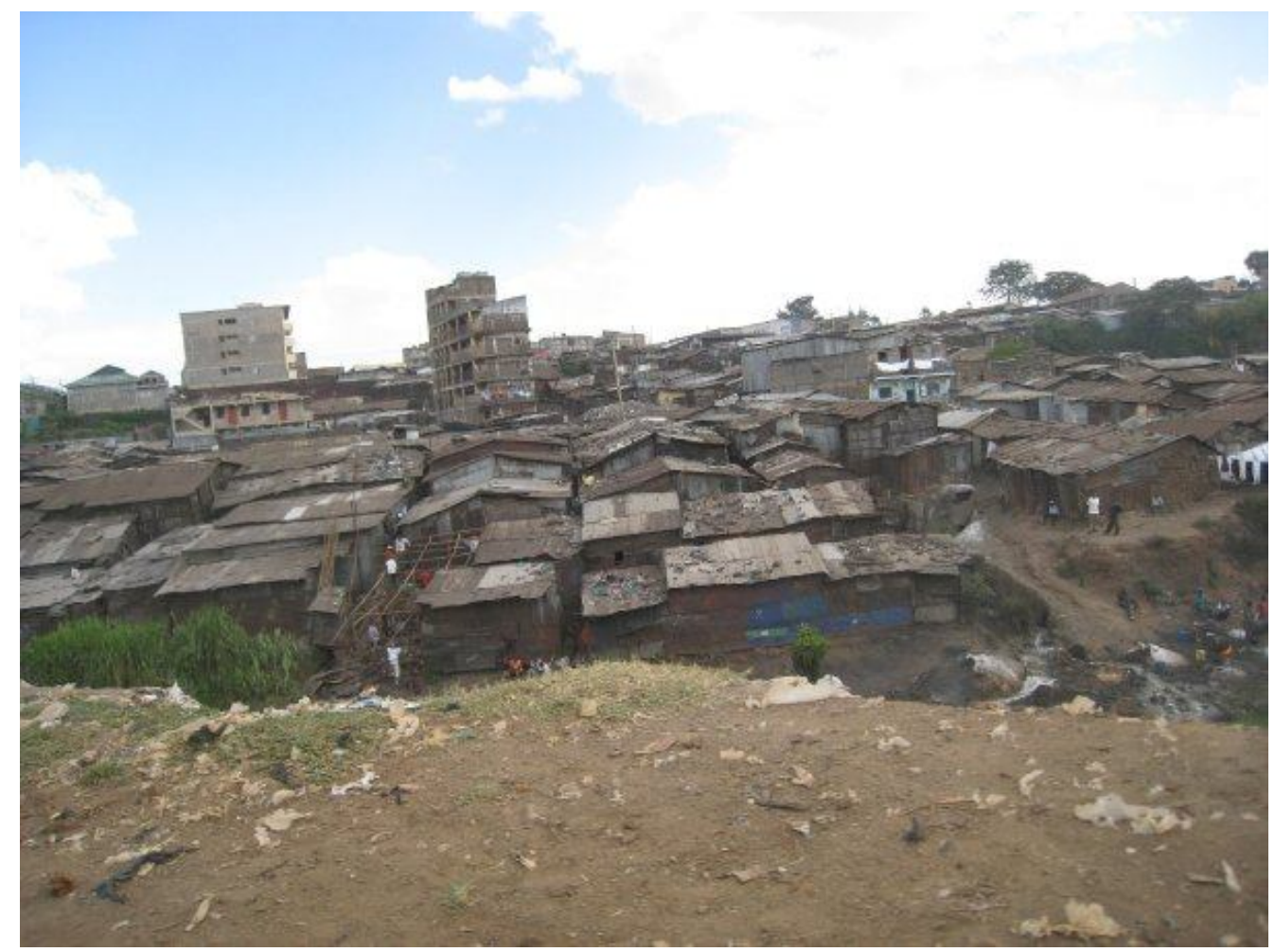

Fig. 2. A view of one part of Mathare

Business District (CBD). Mathare is very densely populated with most people living in shacks made of corrugated iron (mabati), in small streets, and all houses border each other very closely. Mathare is also extremely busy; there is the constant buzz of activity; a cacophony of human voices, children playing and crying; music blurring; and the loud sound of passing public service vehicles (matatus) on the busy main road above. Vendors of vegetables, fruits, meat or fish try to sell their wares wherever a small space is available. The smell of food is prevalent women cook outside on fires made from wood or charcoal. Babies and small children are bathed in the street and alley ways. Children do not use toilet facilities, but relieve themselves outside in the gutter or at the side of the road.

The Mathare environment is far from safe. With no street lights, the evenings and nights are dark and women who walk alone run the risk of being robbed or raped. The houses in Mathare are located in small streets and alleys. By late evening doors leading to these alleys are closed and people can neither enter nor exit their confines. Few people living outside Mathare visit the place. The way people outside Mathare perceive the area is aptly described by the following quote: 'Mathare Valley is referred to as the oldest and the worst slum in Africa ... It is a place for criminals, drug addicts, the unemployed and prostitutes. Many people are afraid to visit here because the crime rate is so high'. ${ }^{1}$

\section{METHODOLOGY}

This case study is a qualitative research effort that examines an unknown and complex situation. A qualitative research methodology creates scope for discussions that eventually reveal a respondent's sincere opinion (Wester and Peters 2004). Often the quality of the research findings is directly dependent on the justifiability of the research method followed (Mukherjee 1983). Consequently, details on the residents' 
perceived QoL and opinions on the issues under investigation are described as conveyed to the researcher by respondents based on their own perspectives. This method of conducting research and of giving an account of the research findings is, according to Howard and DunaifHattis (1992:4), the best method of conveying people's perceptions on the environment in which they live and their daily survival practices.

Qualitative data sources for this study include semi-structured interviews with migrants who arrived at Mathare recently, as well as with long-time residents, tenants, landlords and community leaders. Several methods for information gathering were used: conversations, observations, participation in activities such as churchgoing, attending of a typical day at a school in Mathare, visiting the youth/community centre, participating in women's groups, spending time walking around the area and talking with the residents about what their daily routines consist of. The aim of these activities was to discover patterns that are not visible or detectable with other means of gathering information - interviews for instance (Silverman 2001).

Interviewees were chosen from a variety of age brackets, professions, and social stature (community leaders and ordinary residents); those interviewed included both landlords and tenants. Tenants comprised a majority of interviewees simply because they constitute the majority in the settlement and sub-divisions visited. This paper also draws on interviews with government officials, in particular officials in the Ministry of Housing (councillors for the areas of Mathare and Huruma) and the Nairobi City Council, as well as representatives of international agencies, local non-governmental organisations (NGOs) and community-based organisations working in and around the slums and informal settlements. While individual experiences dominated the interviews, clear patterns and themes emerged about the factors affecting the realisation by slum dwellers of their right to essential services delivery, adequate housing, access to healthcare and a healthy physical environment. In all, 110 formal and informal interviews were carried out with the informal conversations confirming the trends found in the formal interviews.

The questionnaire focussed on the perception of quality of life in Mathare. Some of the questions had to be set specifically to evaluate the level of satisfaction with life in a slum. Enquiries focussed on socio-demographic characteristics, access to water and electricity, waste management in the area, access to sanitation facilities, characteristics and perception of current housing, perception of the neighbourhood environment (location, infrastructure and services) and community environment (protection, participation, social environment). Participants were given the opportunity to give their views on the type of environmental problems that are present in the community and were encouraged to express, honestly, what they feel the local government authorities could/should do to improve their quality of life.

Besides discussions with CCN councillors, for more information on the role and function of local government institutions in service delivery to urban areas, official local government documentation (The City Council of Nairobi Service Charter) proved useful. The actual service provision situation in the settlement is compared to the criteria for sufficient and reasonable services provision as determined by the $\mathrm{CCN}$. Consequently, meaningful and sensible conclusions can be reached on how the standard of service delivery within Mathare ultimately influences the residents' quality of life.

\section{RESULTS}

In this section the results of the formal and informal interviews, inquiries and observations of life and people of Mathare are presented and discussed. Aspects on the general demographic information of respondents, reasons for migrating into Mathare, opinions on service delivery, quality of life and community safety are discussed. Though not all respondents answered all the questions, a general trend could be drawn on aspects of the inquiry from the answers.

\section{Characteristics of Respondents: General Demographic Information}

In total, $8 \%$ of the interview respondents were leaders in the Mathare community - councillors, pastors, church elders, school teachers, a headmaster and a social worker. The interviewed comprised more men $(60 \%)$ than women $(40 \%)$. The growth of slum populations is primarily a result of rural-urban migration by young 
people seeking jobs, as demonstrated by the relatively high proportion of men in the economically active age group (18-50) and the low proportion of women in the same age bracket.

The largest group of interviewees fell in the age groups of 18-24 (40\%) and 25-30 (22\%) respectively, while the rest of the composition is as follows: $31-40(16 \%), 41-50(10 \%)$ and 51 and over (9\%). A higher proportion of the respondents were married (44\%) than single (38\%). Respondents gave Dohluo (31\%), Kikuyu (18\%), and Luhya (16\%) as their home language, while the rest was made up by Kiswahili, Kalenjin and Kisii speakers. One interesting fact is that $1 \%$ of the respondents gave Somali as their home language, indicating that there are a few international migrants living in slums such as Mathare.

\section{Rural-urban Migration and Rapid Urbanisation}

The forces motivating rural-urban migration to Nairobi include better economic prospects, opportunities for higher education and higher wage employment, and the attraction of Nairobi as a market for goods and services. Migration is a dynamic social process of geographical movements by individuals or groups for the purpose of changing residence and improving the quality of life (Cliggett 2000).

The majority of the respondents in Mathare were relatively well settled in the community with $47 \%$ of them having been living in their area for over 3 years. The rest of the residents had been living in Mathare for between 1 and 3 years $(24 \%)$, less than a year $(11 \%)$ and less than 6 months (7\%). Most of the respondents said they had come to Mathare from other parts of Nairobi $(34 \%)$, while $16 \%$ had migrated from the Rift Valley, $14 \%$ had come from the Western Province, $13 \%$ had moved from the Central Province, $11 \%$ were from the Eastern Province and 10\% said they had come from the Nyanza Province.

Approximately half of the respondents (54\%) had completed primary school, while $14 \%$ had a secondary qualification and $4 \%$ had a tertiary qualification. The figure for 'no schooling whatsoever' stood at $28 \%$. Most of the primary schools in Mathare are informal. This means that they are founded by people who are not recognised as teachers by the Government and such schools do not receive support from the Government for school books, rent or salaries for the teachers. Most informal schools ask for a contribution from the parents who send their children to that school. But many of them do not pay, or pay very little.

A majority (65\%) gave 'to seek employment' as the reason for moving to Mathare. It turned out that $39 \%$ of respondents were self-employed in the informal sector while $16 \%$ had no form of employment whatsoever. Work in the formal sector is mostly unskilled labour at an informal (jua kali) market. Even when it comes to employment, the gender difference is evident. Typical jobs for men in Mathare include owning/running a small shop $(d u k a)$. A few of the men surveyed said they work in their own workshop as carpenters or dealing with electronic devices. Some men work as teachers or are in charge of the public toilets, collecting the fee for use of the toilet. Men hardly sell vegetables in the street; that is considered a job for women and children. Unemployed men typically stay at home. They are not active in the household, but just hang around, chatting with other men.

Women, on the other hand, are in charge of the household chores. Houses do not have water faucets, so they are the ones responsible for collecting water from a public tap. They make all the meals when there is money for food. They do all the chores including all the cleaning, laundry and child-rearing. If men live alone, they will do the household chores themselves. However, as soon as there is a woman in the house, she is automatically the one in charge of all household activities.

Due to all their activities in the household, women are not as mobile as men. Some women find housework (cleaning jobs) in the city when they secure employment with wealthier families. Over half of the women respondents were unemployed at the time of the survey, and of those working, a few were employed (by non-relatives) while others were self-employed or involved in the family businesses in the jua kali market.

\section{Service Delivery and Quality of Life}

The relevant authority for service delivery across Nairobi is the City Council (CCN). The councillor for Mathare at the time (September 2009) was identified as Mr Gachenga. Interviews were held with Councillor Gachenga and his colleagues at their offices in Nairobi's City Hall. From the discussions, it was revealed that Nairobi's service delivery is governed by the City of 
Nairobi's Strategic Plan (2006-2010) and Service Charter. The CCN further derives its mandate from Acts of Parliament, including the ones governing the local government.

The mandate of the Plan and the Charter is "to provide and manage basic social and physical infrastructure to the residents of Nairobi. These services include basic education, housing, health, water and sewerage, refuse and garbage collection, planning and development control, urban public transport and fire services and fire brigade, among others" (CCN 2010a: 2).

The mission of the $\mathrm{CCN}$ is to facilitate coordinated development and improved service delivery to stimulate economic activity and high quality of life, and to become one of the most attractive cities of the world (CCN 2010b).

However, residents in Mathare felt that all services - waste management, health services, running water, electricity, sanitation, police services, education, and housing - delivered by local government were insufficient. When asked to choose what they thought to be the most important service to them, respondents listed sanitation (98\%), waste management (98\%), running water $(97 \%)$, healthcare $(97 \%)$ and affordable housing (90\%). Under the same discussion, respondents were asked what services they felt were in shortage in their area. Every respondent $(100 \%)$ agreed that sanitation was in shortage, followed by electricity ( $99 \%)$, waste management $(98 \%)$, running water $(98 \%)$, healthcare $(96 \%)$, affordable housing (95\%), tarred roads $(80 \%)$ and education $(76 \%)$.

With regards to accommodation, it emerged that $85 \%$ of the respondents were renting their dwellings, $8 \%$ were living with a relative, $4 \%$ were living with a friend and only $1 \%$ owned the dwelling they stayed in. The majority of respondents $(70 \%)$ were living in informal shacks made of mabati (corrugated iron) and other low-cost materials, $14 \%$ were living in high-rise flats made of stone and cement, $7 \%$ were living in rooms in a backyard, 5\% were living in shacks in a backyard and $1 \%$ lived in a house or brick structure on a stand.

Over half of the respondents $(61 \%)$ use coal for cooking and heating. The rest make use of wood $(50 \%)$ for cooking and heating, paraffin (38\%) for lighting and illegally connected electricity $(11 \%)$ for lighting, cooking and heating. Most of the respondents (54\%) rely on commu- nal standpipes for water. A further $18 \%$ said they purchased their water from a vendor (water kiosk) and $13 \%$ collected from an open source (well). Only $1 \%$ had pipe water in their yard.

Sanitation facilities in Mathare are very basic and are few. Such facilities consist of communal water taps and pit latrines utilised by several people living in the area. The area lacks systematic solid waste disposal (see Fig. 3) and decent ablution facilities with some residents resorting to the use of what is analogously referred to as 'flying toilets' - whereby desperate slum-dwellers relieve themselves in plastic bags and throw them out during the night. The bags land anywhere, in pathways, in open fields and on the roofs of neighbouring shacks. This problem is not unique to Mathare and can be found happening in many other slums in Nairobi. When it comes to toilet facilities, $83 \%$ of the interview respondents use a communal pit latrine, while the rest use other pit latrines $(5 \%)$, flush toilets (3\%), buckets (3\%) and 'flying toilets' $(3 \%)$.

In Mathare, there is no infrastructure for waste removal and garbage just piles up all over the area (see Fig. 3). In the rest of the city, people have resorted to getting rid of their own waste or hiring private companies to collect it for them. The City Council has no reliable service in place for waste management. Due to the lack of waste management infrastructure in Mathare, people throw their garbage alongside the road and there are certain spots where garbage accumulates between the houses. There it lies, rotting and smelling.

Many factors specific to the informal settlement context contribute to the low quality of life of the residents. Environmental factors include physical factors that have a direct effect on health, such as overcrowding, poor water and sanitation and poor hygiene which all increase the risk of communicable diseases; and social factors such as alienation, unemployment, ethnic tensions and violence which tend to lower the quality of life.

\section{Quality of Life-A Subjective Reality}

Residents were asked whether they thought that the $\mathrm{CCN}$ was doing enough in their community regarding service delivery. Those who strongly disagreed were $98 \%$ while $1 \%$ disagreed and another $1 \%$ was undecided. A large number $(39 \%)$ of respondents felt that during their time 


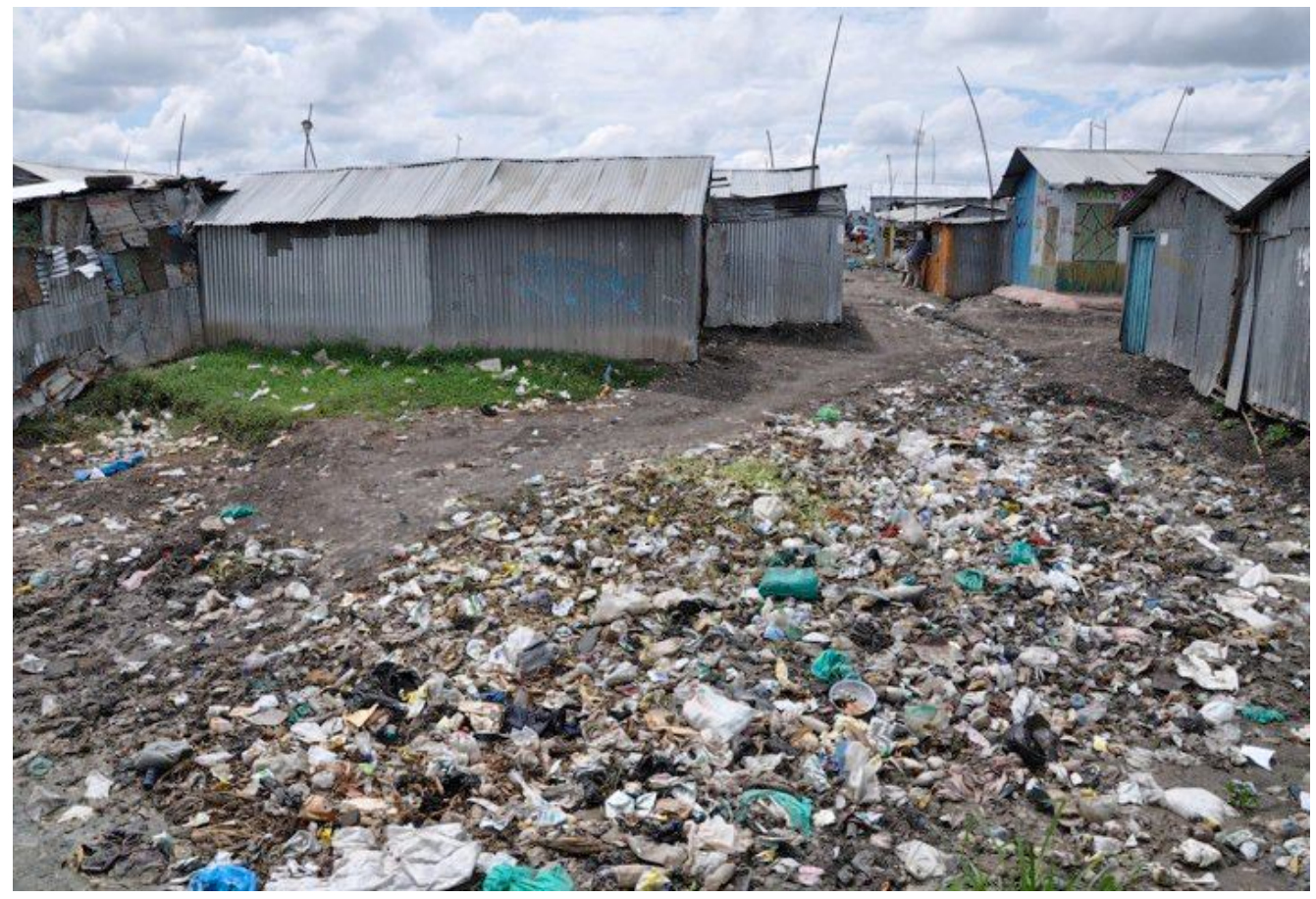

Fig. 3. An area in Mathare where solid waste has piled up

in Mathare, none of the services in the area had improved. In terms of social issues and security services, a large number of respondents $(88 \%)$ said that street fights were a problem in the area, followed by political/ethnic conflict (73\%) and alcohol/drug-induced violence (63\%). When quizzed about the role of the police services, $60 \%$ of respondents strongly disagreed that the police in the area were doing enough to stop crime, unrest and violence.

The study revealed that the majority of Mathare residents were not only dissatisfied with their lives generally, they also expressed discontent with a range of specific aspects of their lives. This included, amongst others, income, employment, schooling, housing and recreation facilities. Möller (1992) has observed that, when broad social conditions improve or deteriorate, the people's reported levels of happiness responds accordingly. Residents in Mathare complain about their situation. When people do not see any possibility to change their life, all they can do is complain and wait. Besides the lack of services mentioned above it became clear, from the discussions with various residents and com- munity leaders in Mathare, that there was a host of other factors that dictated their levels of satisfaction with their quality of life. These included social status, distrust and insecurity, dependence, identity, groups and churches, and social organisation and relations. All these factors seemed to feature in conversations with residents when questioned about what makes them happy, what they consider to be important in their lives and how these things could be improved.

\section{Empowering the Community and Improving the Quality of Life}

Over three decades ago, Koza (1976:60), pointed out that in any programme which aims at improving the socio-economic condition of a people, the people concerned need not only be recognised, they must also be part of decisionmaking concerning affairs that affect them. The people themselves must be agents of change and the government should only facilitate this by providing infrastructural support (De Clerq 1994:385). Literature on development and inter- 
national agencies alike agree that, for community involvement to be effective and self-sustaining, the community should be involved at all stages.

Empowering the community within the environment of an established slum area in enhancing its quality of life could be seen as a process that will assist in addressing the issue effectively. In Mathare, vibrant and resourceful youth groups have taken initiatives to improve the living conditions of the community. The actions of these residents are proof of the commitment to an improved quality of life that exists among the majority of people living there. Their experiences of negative living conditions have channelled part of the community into analysing their situation and considering ways of instituting projects that would help alleviate poverty and improve the general quality of life.

Mostly unemployed and facing a host of challenges, some of the youth in Mathare are joining together and bringing about small-scale positive changes in their own communities in a bid to uplift the QoL in the area. One of these groups is Kamaliza - a community-based organisation (CBO) in Mathare. Members collect garbage and waste, clear spaces for community gardens and set up recycling projects. They also offer mentoring and empowering activities such as sports and cultural events for kids. According to one of the members of the waste collection group, "Kamaliza has been helpful to us residents in this neighbourhood. All the garbage collected from the households is recycled here. You can see it is benefiting the people working in it. At Kamaliza we deal with collecting garbage at households, after which we separate the plastic, metal and paper. Then we shred the sorted plastic, after which we package and sell to the industries. The money that we have collected has helped us to buy a washing machine, which adds value to the plastic we have shredded. We are able to wash the plastic so that we can get a better price from the customer. When we collect this garbage, we are able to earn a living, while keeping the community clean. At least to have a clean environment for our children and future generations" (Fred Astari, member of Kamaliza).

'Manygro' is another such group. One of its progressive initiatives was an urban garden where onion, kale and spinach are cultivated in sacks. The community has been trained by mem- bers of the Manygro group on planting their vegetables using a kind of multi-layered urban garden system. The group is also responsible for a chicken coop and a toilet block. The group tasks itself with keeping the toilets clean and charging users KSH 2.00 (US\$ 0.02) per use. Around 200 to 500 people in the immediate neighbourhood use the busy toilets.

The Mathare case study illustrates how residents in low-income areas are coming up with innovative approaches for dealing with the social and environmental problems they face. With the assistance of some NGOs and other actors, partnerships could have some considerable success. It is clear that the residents of Mathare are now looking at ways of becoming more involved in improving the quality of their lives and of their living environment.

\section{CONCLUSION}

The findings of this research suggest that the residents of urban slums and informal settlements such as Mathare are aware of the role and function of local government institutions such as the $\mathrm{CCN}$. The discussion on the survey findings indicated that the residents of Mathare perceive their QoL to be influenced negatively by the settlement's service provision situation. The fact is that the residents do not have easy and consistent access to basic CCN services that other parts of the city enjoy. Clearly the main route to improving the quality of life is through the provision of essential services such as pipe water and sanitation. In addition, employment for job-seekers and schools for children are a necessity.

However, from the interactions and discussions it became evident that an improved quality of service delivery is not in itself enough to completely satisfy residents and ensure happiness. According to the residents, other aspects of everyday life that influence their QoL includes activities of which success depends on the actions of the individual. These activities included things that had nothing to do with the local government and basic service provision. They comprised: church-going, social status, identity, personal insecurity brought on by distrust of neighbours and other community members, and social organisation. It can thus be concluded that an improved delivery of services creates the potential for a higher QoL, but that the real- 
isation of that dream remains in the hands of the residents themselves.

There are a number of organisations and agencies present in Mathare who have occasionally brought in basic services to Mathare, such as sanitation facilities (compost toilets and communal pit latrines), free mobile health (clinic) services, and community centres to offer educational courses to the residents. Such activities should be commended and mainstreamed. Indeed, through this periodical provision of services Mathare residents became exposed to the benefits of some basic services and have learnt that their daily lives would be easier if they had consistent access to an improved system of service delivery.

Since Mathare lacks basic amenities - housing, sanitation, waste management, drainage, electricity, running water and a proper road network - community lifestyles will inevitably lead to the further damaging of the environment if these amenities are not provided. This is already visible (as seen in Fig. 3) where a lack of waste management and sanitation results in pollution. It is however encouraging to note that groups have banded together and begun to do things for themselves, to form community organisations geared towards obtaining their own community services and improving conditions within Mathare.

\section{RECOMMENDATIONS}

Sustaining improved quality of life for the residents of Mathare will require the community to have a capability of meeting their needs. This is best achieved by creating avenues for community participation in decision making concerning issues of job creation, community projects and the provision of social services. The motive for government and its institutions should be one of facilitating and helping communities into taking ownership of economic and social issues that directly affect their lives. By this, sustainable employment creation through self-help projects could become a reality. Much more still needs to be done to enable the community to access basic services such as sanitation facilities, improved waste management, housing, water and electricity. Whilst provision of such services would not only improve lives but also save the environment from further destruction, curbing rural to urban migration through rural development offers a more permanent long term solution to the deteriorating quality of life in urban slums. Further qualitative research should be conducted to establish the gap between objective living conditions and subjective life satisfaction among communities. By this policy objective setting, formulation and implementation - with a view to improving the quality of life of the urban poor - could be enhanced.

\section{NOTE}

1. About Mathare Valley. Available at: http://www. matharevalley.org.

\section{REFERENCES}

Atte OD 1983. From inside looking out: An Emic perspective of life quality in Nigeria: A case study from Kwara State, Nigeria. In: U Igbozurike, R Raza (Eds.): Rural Nigeria: Development and Quality of Life, pp $213-237$. Proceedings of the Seminar on "Quality of Life in Rural Nigeria". Ilorin: Agriculture and Rural Management Training Institute, July 6 to $7,1983$.

Bekker S 1992. Shelter from the storm: Needs in a new world. Indicator South Africa, 9(2): 59-62.

Beukes E, Van der Colff A 1997. Aspects of the quality of life in black townships in a South African city: Implications for human development. Social Indicators Research, 41: 229-250.

Campbell EH 2005. Formalizing the informal economy: Somali refugee and migrant trade networks in Nairobi. Global Migration Perspectives, 47: 135164.

Care International 2009. Internal Review of the Provision of Relief Assistance to Communities Affected by Post-Election Violence Project Jan-June 2008. From <http://givewell.org/files/DWDA\% 202009/Concern/Kenya Techni-calBrief09.pdf> (Retrieved May 8, 2010).

Central Bureau of Statistics (CBS) 2001. Counting our people for development. Population and Housing Census. Vol.1. Nairobi: Central Bureau of Statistics.

Central Bureau of Statistics (CBS) 2008. Statistical Abstract (2008). Nairobi: Central Bureau of Statistics.

City Council of Nairobi (CCN) 2010a. Service Charter. Nairobi, Kenya.

City Council of Nairobi (CCN) 2010b. Strategic Plan 2006-2010. Nairobi, Kenya.

Central Intelligence Agency (CIA) World Factbook 2010. From <https://www.cia.gov/library/publications/the-world-factbook/geos/ke.html> (Retrieved June 3, 2010).

Centre on Housing Rights and Evictions (COHRE) 2008. Women, Slums and Urbanisation: Examining the Causes and Consequences. COHORE: Geneva, Switzerland. 
Cliggett L 2000. Social components of migration, experiences from Southern Province, Zambia. Human Organizations, 59(1): 125 - 135 .

Davies B 1993. Empowering the poor: Capacity building in the Eastern Cape. Indicator South Africa, $11(1): 37-43$

De Clerq F 1994. Putting community practice into development work: The difficult case of Winterveld. Development Southern Africa, 1(3): 379393.

Diener E, Suh E 1997. Measuring quality of life: Economic, social, and subjective indicators. Social Indicators Research, 40: 189-216.

Hagerty MR, Cummins RA, Ferriss AL, Land K, Michalos AC, Peterson M 2001. Quality of life indexes for national policy: Review and agenda for research. Social Indicators Research, 55: 1-96.

Howard MC, Dunaif-Hattis J 1992. Anthropology Understanding Human Adaptation. New York: Harper-Collins.

Huitt W 2007. Maslow's Hierarchy of Needs, Educational Psychology Interactive, Valdosta State University, Georgia. From < http://www. edpsycinteratcive.org/topics/regsys/maslow.html> (Retrieved March 12, 2010).

Koza C 1976. Human development: A crucial factor for community development. In: J Barrat (Ed.): Strategy for Development. London: MacMillan Press, pp. 30-45.

Lombard A 1991. Community work in relation to community and social action, community organisation, social planning and community development. In: A Lombard, L Mike, J Weyers, H Schoeman (Eds.): Community Work and Community Development. Kenwyn: Juta, pp. 57-122.

Maslow A 1943. A Theory of Human Motivation. Psychological Review, 50, pp. 370-396. From <http:/ /psychclassics.yorku.ca/Maslow/motivation.htm> (Retrieved June, 2010)

Mngoma LW 1997. Enhancing Quality of Life in the Informal Settlement of Hemfane Area, KwazuluNatal: A Study in Community Development. MA Dissertation, Unpublished. University of Pretoria, Pretoria.

Möller V 1992. A place in the sun: Quality of life in South Africa. Indicator South Africa, 9(4): 101108.

Mukherjee R 1983. Quality of Life. London: Sage Publications.

Munslow B, Fitzgerald P 1994. Sustainable development: Turning vision into reality. In: B Munslow,
P Fitzgerald, A McKennan (Eds.): Managing Sustainable Development in South Africa. Cape Town: Oxford University Press, pp. 3-38.

Ndlovu F, Fairhurst J 1996. The Ogies-Phola development forum as an example for South Africa's communities. Development Southern Africa, 13(2): 265-275.

Nussbaum M, Sen A 1993. The Quality of Life. Oxford: Clarendon Press.

Rakodi C 1997. The Urban Challenge in Africa. Growth and Management of its Large Cities. Tokyo: United Nations University (UNU) Press.

Scheer L 1980. Experience with quality of life comparisons. In: A Szalai, FM Andrews (Eds.): The Quality of Life. Oxford: Sage Studies in International Sociology, pp. 145-155.

Sen A 1999. Development as Freedom. New York: Anchor Books.

Silverman D 2001. Interpreting Qualitative Data. Methods for Analysing Talk, Text and Interaction. London: Sage Publications.

Society for International Development (SID) 2006. Readings on Inequality in Kenya. Sectoral Dynamics and Perspectives. Nairobi: Regal Press Kenya Ltd.

Todaro MP 1994. Economic Development. Singapore: Longman

United Nations Development Programme (UNDP) 2007. Human Development Report. New York: Mcmillan.

United Nations Human Settlements Programme (UNHabitat) 2009. The UN-Habitat Urban Youth Fund Promotional Videos. Nairobi: UN-Habitat.

United Nations Human Settlements Programme (UNHabitat) 2010. State of the Worlds Cities 20062007. The Millennium Development Goals and Urban Sustainability. Nairobi: UN-Habitat.

Westaway MS 2006. A longitudinal investigation of satisfaction with personal and environmental quality of life in an informal South African housing settlement, Doornkoop, Soweto. Habitat International, 30: 175-189.

Wester F, Peters V 2004. Qualitative Analysis: Outcomes and Procedures. Coutinho: Bussum.

World Bank (WB) 2006. World Development Report 2006. From <www.worldbank.org/wdr.> (Retrieved May 8, 2010).

Young K 1993. Planning Development with Women: Making a World of Difference. London: Macmillan Press. 